\title{
LingTera
}

Volume 2 - Nomor 1, Mei 2015, (38 - 50)

Available online at LingTera Website: http://journal.uny.ac.id/index.php/ljtp

\section{PERAN SIMPLE CODE DALAM KOREKSI KESALAHAN BERBAHASA PESERTA DARMASISWA DI UNIVERSITAS MUHAMMADIYAH SURABAYA}

\author{
Ngatma'in ${ }^{1)}$, Suhardi ${ }^{2)}$ \\ Universitas Muhammadiyah Surabaya ${ }^{1)}$, Universitas Negeri Yogyakarta ${ }^{2)}$ \\ dirjopenewu@gmail.com ${ }^{1)}$, suhardi@uny.ac.id ${ }^{2)}$
}

\begin{abstract}
Abstrak
Tujuan penelitian ini adalah untuk mengetahui peran simple code dalam koreksi kesalahan berbahasa peserta Darmasiswa di Universitas Muhammadiyah Surabaya tahun ajaran 2011/2012. Penelitian ini menggunakan metode kualitatif. Penelitian ini dilaksanakan di kelas Darmasiswa Program Studi Pendidikan Bahasa dan Sastra Indonesia Fakultas Keguruan dan Ilmu Pendidikan Universitas Muhammadiyah Surabaya mulai November 2011 sampai April 2012. Sumber data penelitian ini adalah bentuk ujaran yang dihasilkan oleh dosen, penutur, dan peserta Darmasiswa. Instrumen pengumpulan data dilakukan dengan cara pengamatan, wawancara, dan dokumentasi. Instrumen penelitian ini adalah peneliti sendiri. Analisis data menggunakan metode padan intralingual. Hasil penelitian ini adalah sebagai berikut. (1) Peran bahasa dosen (teacher-talk) memberikan koreksi kesalahan berbahasa Indonesia peserta Darmasiswa dalam hal kesalahan fonologis, sintaksis, leksikon, dan morfologis. Jenis koreksi berupa pengulangan, mengubah, koreksi eksplisit, pancingan, dan klarifikasi. (2) Peran bahasa penutur (foreigner-talk) memberikan koreksi kesalahan berbahasa Indonesia peserta Darmasiswa dalam hal kesalahan fonologis, sintaksis, dan leksikon. Jenis koreksi berupa pengulangan, mengubah, dan koreksi eksplisit. (3) Peran bahasa-antara (interlanguage-talk) memberikan koreksi kesalahan berbahasa Indonesia dalam hal kesalahan fonologis dan kesalahan leksikon. Jenis koreksi berupa koreksi diri dan koreksi teman.
\end{abstract}

Kata Kunci: peran simple code, koreksi kesalahan berbahasa, darmasiswa.

\section{THE ROLE OF THE SIMPLE CODE IN THE CORRECTION OF LANGUAGE MISTAKES MADE BY THE DARMASISWA PARTICIPANTS IN THE MUHAMMADIYAH UNIVERSITY OF SURABAYA}

\begin{abstract}
This study aims to find out the role of the simple code in the correction of language mistakes made by the Darmasiswa participants in the Muhammadiyah University of Surabaya in the academic year of 2011/2012. This study employed the qualitative method. It was conducted in the Darmasiswa class of the Study Program of the Indonesian Language and Literature, the Faculty of Teacher Training and Educational Sciences, the Muhammadiyah University of Surabaya from November 2011 to April 2012. The data sources in this study were the forms of utterances by lecturers, speakers, and Darmasiswa participants. The data were collected through observations, interviews, and documentation. The research instrument was the researcher himself. The data were analyzed using the intralingual correspondence method. The results of the study are as follows. (1) The role of the teacher-talk in the correction of the Indonesian language mistakes made by the Darmasiswa participants is in phonology, syntax, lexicon, and morphology. The types of the correction include repetition, modification, explicit correction, stimulation, and clarification. (2) The role of the foreigner-talk in the correction of the Indonesian language mistakes made by the Darmasiswa participants is in phonology, syntax, and lexicon. The types of the correction include repetition, modification, and explicit correction. (3) The role of the interlanguage-talk in the correction of the Indonesian language mistakes is in phonology and lexicon. The types of the correction include self-correction and peer-correction.
\end{abstract}

Keywords: role of the simple code, correction of language mistakes, darmasiswa. 


\section{PENDAHULUAN}

Darmasiswa adalah program beasiswa yang diberikan untuk mahasiswa asing dari negara yang memiliki hubungan diplomatik dengan negara Indonesia. Peserta Darmasiswa bertujuan untuk belajar bahasa Indonesia, seni tari, karawitan, musik, seni kriya, batik, seni rupa, fotografi, dan kuliner. Program ini diselenggarakan oleh Kementerian Pendidikan Nasional yang bekerja sama dengan Kementerian Luar Negeri.

Pembelajaran bahasa Indonesia untuk penutur asing (BIPA) dilandasi oleh pertimbangan bahwa dalam era global peranan penting telah dimiliki oleh bangsa Indonesia di dunia internasional. Peranan penting tersebut adalah hubungan kerja sama di berbagai sektor. Untuk meningkatkan pemahaman bangsa lain terhadap bangsa dan budaya Indonesia, bahasa Indonesia satusatunya lingua franca yang tepat bagi bangsa lain. Populasi penduduk, letak geografis, keindahan alam, kebudayaan, dan perusahaan asing menjadi penyebab banyak orang asing ingin belajar bahasa Indonesia (Iskandarwassid \& Sunendar, 2009, p.262).

Saat ini, berbagai perguruan tinggi negeri dan swasta menyelenggarakan pengajaran BIPA. Universitas Muhammadiyah Surabaya bekerja sama dengan Kementerian Pendidikan Nasional untuk menyelenggarakan pembelajaran berbahasa Indonesia untuk peserta Darmasiswa sejak 2006 sampai sekarang.

Berbagai kegiatan pembelajaran dilakukan secara formal dan informal. Pembelajaran formal dilaksanakan di kelas. Kegiatan informal dilaksanakan di luar jam pelajaran. Beragam kegiatan informal diikuti peserta Darmasiswa, seperti kunjungan ke Pusat Bahasa Jawa Timur, Museum Mpu Tantular, Balai Kesenian Cak Durasin, Balai Pemuda, tempat wisata, kegiatan pelatihan organisasi mahasiswa, latihan tari Remo, latihan seni bela diri Tapak Suci, dan kegiatan ilmiah lainnya.

Proses pembelajaran terdapat berbagai permasalahan yang muncul. Permasalahan yang paling mendasar adalah kesalahan berbahasa peserta Darmasiswa. Permasalahan tersebut dipengaruhi oleh beberapa faktor. Pertama, peran bahasa dosen dalam proses pembelajaran berbahasa Indonesia kepada peserta Darmasiswa. Untuk memudahkan pembelajaran, dosen menggunakan bahasa asing yang dipahami oleh pembelajar, bukan bahasa target. Kedua, peran bahasa penutur terhadap perkembangan pembel- ajaran berbahasa Indonesia bagi peserta Darmasiswa. Penutur menggunakan bahasa yang tidak sama dengan bahasa target. Ketiga adalah penggunaan bahasa-antara oleh peserta Darmasiswa. Dalam proses komunkasi, pembelajar menggunakan bahasa yang dipahami oleh kelompok mereka.

Bahasa dosen sangat mempengaruhi keterampilan berbahasa peserta Darmasiswa. Bahasa dosen harus memberikan kemudahan bagi peserta Darmasiswa dalam mempelajari bahasa target. Bahasa dosen harus memberikan ciri-ciri sebagai bahasa yang tepat dalam proses pembelajaran berbahasa Indonesia bagi peserta Darmasiswa. Salah satu ciri bahasa dosen dalam pembelajaran bahasa asing adalah kesederhanaan bahasa yang digunakan dosen dalam pembelajaran di kelas.

Bahasa penutur juga mempengaruhi keterampilan berbahasa peserta Darmasiswa. Bahasa penutur mendukung bagi peserta Darmasiswa dalam mempelajari bahasa target. Bahasa penutur harus memberikan ciri-ciri sebagai bahasa yang tepat dalam proses pembelajaran berbahasa Indonesia bagi peserta Darmasiswa. Salah satu ciri bahasa penutur adalah lebih lambat dan lebih nyaring daripada ujaran normal.

Bahasa-antara juga mempengaruhi keterampilan berbahasa peserta Darmasiswa. Bahasa-antara memberikan jembatan bagi peserta Darmasiswa dalam mempelajari bahasa target. Bahasa-antara memberikan ciri-ciri sebagai bahasa yang tepat dalam proses pembelajaran berbahasa Indonesia bagi peserta Darmasiswa. Salah satu ciri bahasa-antara adalah menggunakan pola bahasa ibu dan memperpanjang pola bahasa target dalam peristiwa komunikasi.

Bahasa dosen, bahasa penutur, dan bahasa-antara memberikan kemudahan, dukungan, dan jembatan bagi peserta Darmasiswa dalam proses pembelajaran berbahasa Indonesia. Dalam pembelajaran berbahasa, ketiga bahasa tersebut diistilahkan dengan simple code (Krashen, 2002, p.120).

Krashen (2002, p.120) menyebutkan tiga jenis simple code yaitu: teacher-talk, foreignertalk, dan interlanguage-talk. Teacher-talk adalah ragam bahasa yang digunakan dosen ketika mengajar peserta Darmasiswa di kelas. Foreigner-talk adalah bahasa penutur yang digunakan untuk berkomunikasi dengan peserta Darmasiswa yang belum menguasai bahasa target. Interlanguage-talk adalah bahasa-antara peserta Darmasiswa ketika berkomunikasi menggunakan bahasa terget. 
Harimansyah W, et al. (2008, p.1) menyebutkan faktor pendukung kelancaran proses belajar mengajar Bahasa Indonesia bagi Penutur Asing (BIPA) adalah pengajar dan bahan ajar. Pengajar BIPA adalah orang-orang yang telah berpengalaman mengajarkan bahasa Indonesia sebagai bahasa asing. Pengajar harus berlatar belakang pendidikan bahasa, memahami aneka kesulitan yang dialami oleh para pembelajar yang berbeda latar belakang sosial dan budayanya. Bahan ajar dan fasilitas yang digunakan dalam pembelajaran BIPA harus dapat menunjang pembelajaran. Bahan ajar dan fasilitas tersebut adalah (1) ruang kelas yang representatif, (2) buku, kaset, dan CD bahan ajar, (3) perpustakaan, dan (4) laboratorium bahasa. Selain beberapa faktor tersebut, faktor pembelajar juga dapat mempengaruhi proses belajar bahasa kedua. Pembelajar bahasa kedua harus memiliki komitmen, keterlibatan total, respon fisik, intelektual, dan emosional total demi keberhasilan pembelajaran bahasa target (Brown, 2008, p.1).

Gambaran pembelajaran keterampilan berbahasa Indonesia bagi peserta Darmasiswa sangat unik untuk dikaji. Khusus di Universitas Muhammadiyah Surabaya, peran bahasa dosen, bahasa penutur dan bahasa-antara dalam pembelajaran belum pernah dilakukan pengkajian yang lebih dalam.

Merujuk pada latar belakang tersebut, penelitian ini mengemukakan beberapa rumusan masalah sebagai berikut. (1) bagaimanakah peran bahasa dosen (teacher-talk) dalam koreksi kesalahan berbahasa Indonesia peserta Darmasiswa? (2) bagaimanakah peran bahasa penutur (foreigner-talk) dalam koreksi kesalahan berbahasa Indonesia peserta Darmasiswa? dan (3) bagaimanakah peran bahasa-antara (interlanguage-talk) dalam koreksi kesalahan berbahasa Indonesia?

Tujuan penelitian diuraikan sebagai berikut. (1) memperoleh rincian peran bahasa dosen (teacher-talk) dalam koreksi kesalahan berbahasa Indonesia peserta Darmasiswa, (2) memperoleh rincian peran bahasa penutur (foreignertalk) dalam koreksi kesalahan berbahasa Indonesia peserta Darmasiswa, dan (3) memperoleh rincian peran bahasa-antara (interlanguage-talk) dalam koreksi kesalahan berbahasa Indonesia.

Manfaat penelitian terdiri atas manfaat teoretis dan manfaat praktis. Secara teoretis hasil penelitian ini diharapkan dapat memberikan sumbangsih bagi pengembangan pembelajaran bahasa Indonesia sebagai bahasa asing. Pengem- bang pembelajaran dapat melakukan klasifikasi kesalahan berbahasa yang dilakukan mahasiswa. Klasifikasi dapat memberikan informasi bentuk kesalahan dan cara mengatasinya. Usaha mengatasi kesalahan berbahasa dapat dilakukan dengan cara membuat bahan ajar yang tepat bagi peserta Darmasiswa. Misalnya, dibuatkan bahan ajar yang berbasis kesalahan pembelajar berbahasa Inggris, Thailand, atau Madagaskar. Secara praktis hasil penelitian diharapkan dapat memberikan informasi peran simple code dalam koreksi kelasahan berbahasa peserta Darmasiswa. Mahasiswa dapat mengetahui kualitas dan kuantitas keterampilan berbahasa Indonesia. Dosen dapat mengetahui sejauh mana peran yang dilakukan dalam koreksi kesalahan berbahasa Indonesia peserta Darmasiswa.

\section{METODE}

\section{Jenis Penelitian}

Penelitian ini menggunakan metode kualitatif. Bogdan \& Taylor (Moleong, 2012, p.4) menguraikan "metode kualitatif dipakai sebagai prosedur penelitian yang menghasilkan data deskriptif berupa kata-kata tertulis atau lisan dari orang-orang dan perilaku yang dapat diamati."

\section{Waktu dan Tempat Penelitian}

Penelitian dilaksanakan mulai November 2011 sampai April 2012. Penelitian dilaksanakan di kelas Darmasiswa Program Studi Pendidikan Bahasa dan Sastra Indonesia Fakultas Keguruan dan Ilmu Pendidikan Universitas Muhammadiyah Surabaya.

\section{Subjek Penelitian}

Subjek penelitian ini adalah dosen, penutur, dan peserta Darmasiswa. Objek penelitian ini adalah ujaran dosen, penutur, dan peserta Darmasiswa dalam koreksi kesalahan berbahasa peserta Darmasiswa.

\section{Instrumen, dan Teknik Pengumpulan Data}

Setiyadi (2006, pp.230-234) memaparkan berbagai penggunaan metode kualitatif dalam pengajaran bahasa asing berdasarkan cara peneliti mendapatkan data. Cara tersebut adalah introspeksi, pengamatan peran-serta, deskripsi terarah, kaji tindak kelas, dan analisis interksi. Sugiyono (2010, pp.308-332) menyatakan pengumpulan data dapat dilakukan dalam berbagai setting, sumber, dan cara. Instrumen penelitian adalah peneliti sendiri. Pengambilan data dalam penelitian ini menggunakan setting 


\section{LingTera, 2 (1), Mei 2015 - 41 \\ Ngatma'in, Suhardi}

alamiah; sumber data primer. Instrumen pengumpulan data dilakukan dengan cara pengamatan, wawancara, dan dokumentasi.

\section{Teknik Analisis Data}

Analisis data dalam penelitian ini menggunakan metode padan intralingual. Metode padan intralingual adalah metode analisis dengan cara menghubung-bandingkan unsur-unsur yang bersifat lingual, baik yang terdapat dalam satu bahasa maupun dalam beberapa bahasa yang berbeda (Mahsun, 2012, p.118).

\section{HASIL DAN PEMBAHASAN}

Peserta Darmasiswa yang belajar di Universitas Muhammadiyah Surabaya tahun ajaran 2011/2012 berasal dari Thailand, Madagaskar, dan Nepal. Mereka adalah Abbas Changnam, Nooreehan Salae, Wundee Suntong, Pankaj Raj Joshi, dan Razanakoto Narisoa Sylvain Yvon. Bahasa mereka bervariasi, di antaranya bahasa Thailand Selatan, Melayu, Thai, Inggris, Nepali, Hindi, Malagas, Prancis, dan Tanjani.

Peserta Darmasiswa tiba di Universitas Muhammadiyah Surabaya pada 26 September 2011. Pembelajaran dimulai pada bulan Oktober 2011. Pada awal tiba di Indonesia, sebagian besar mereka belum memahami bahasa Indonesia. Untuk keperluan komunikasi dengan dosen, penutur, dan antarpeserta Darmasiswa, mereka menggunakan bahasa Inggris.

Selama di Indonesia, mereka sudah berkunjung ke kota Malang, Mojokerto, Yogyakarta, Jombang, Lamongan, dan Madura. Berkunjung ke berbagai universitas di Indonesia. Mereka dapat menari Remo, Jumpritan, dan tari tradisional lainnya.

Hasil penelitian telah ditemukan beberapa peran Simple Code dalam koreksi kesalahan berbahasa peserta Darmasiswa. Kesalahan berbahasa dalam hal kesalahan fonologis, kesalahan sintaksis, kesalahan leksikon, dan kesalahan morfologis. Jenis koreksi berupa pengulangan, mengubah, koreksi eksplisit, pancingan, klarifikasi, koreksi diri, dan koreksi teman.

\section{Peran Bahasa Dosen (teacher-talk) dalam Memberikan Koreksi Kesalahan Berbahasa Indonesia Peserta Darmasiswa}

Richards, Platt, \& Platt (1992, p.375) menjelaskan bahwa bahasa dosen (teacher-talk) adalah ragam bahasa yang digunakan oleh dosen dalam proses pembelajaran. Dalam situasi komunikasi dengan pembelajar, dosen sering menyederhanakan ujaran dan menyederhanakan gaya berbicara bahasa asing. Bahasa dosen berfungsi sebagai masukan yang paling berharga. Pembelajar percaya bahwa belajar dari bahasa dosen merupakan salah satu strategi pembelajaran yang paling efektif (MA Xiao-yan, 2006, pp.60-61).

Dalam pembelajaran, mahasiswa seringkali mengalami kesalahan berbahasa. Dosen memberikan koreksi kesalahan berbahasa peserta Darmasiswa dalam hal kesalahan fonologis, kesalahan sintaksis, kesalahan leksikon, dan kesalahan morfologis. Jenis koreksi yang dilakukan berupa pengulangan, mengubah, koreksi eksplisit, pancingan, dan klarifikasi. Kajian ini hanya memaparkan beberapa jenis kesalahan berbahasa peserta Darmasiswa dan peran bahasa dosen memberikan koreksi kesalahan. Jenis kesalahan dan jenis koreksi kesalahan dideskripsikan sebagai berikut.

Jenis Kesalahan Berbahasa Peserta Darmasiswa

\section{Kesalahan Fonologis}

Kesalahan fonologis adalah kesalahan yang terjadi karena ketidaktepatan penutur dalam mengujarkan kata tertentu. Ketidaktepatan ini dapat mengakibatkan perubahan makna kata yang dimaksud oleh penutur. Secara fisis kesalahan fonologis dapat diketahui dari bentuk bibir saat menghasilkan suatu ujaran tertentu. Secara auditoris kesalahan fonologis dapat diketahui dari bunyi ujaran yang dihasilkan. Berikut tuturan mahasiswa dan dosen.

(1)

Mahasiswa: Ya. Dan kami tinggal di perumahan di Jakarta dalam tiga hari. Hari selasa [paji], jam tujuh. (25/TT/8/03/2012)

Dosen : Pagi. Bukan ji, pagi.

Mahasiswa: Pagi.

Dosen : Gi.

Mahasiswa: Gi.

Dosen : Ya, bukan paji, gi. Pagi.

Mahasiswa: Pagi.

Dosen : He'e.

Dosen memberikan koreksi eksplisit kesalahan fonetik pada data (25/TT/8/03/2012). Mahasiswa kurang tepat dalam mengujarkan kata [pagi]. Dosen meminta mahasiswa untuk melafalkan kembali kesalahan kata tersebut dengan cara memberikan penekanan pada suku kedua pada kata [pagi] tersebut. Kata [pagi] diujarkan menjadi [paji]. Dilihat dari mekanisme artikulasi, huruf [g] tergolong bunyi dorso-velar, yaitu bunyi yang dihasilkan oleh keterlibatan 
pangkal lidah (dorsum) dan langit-langit lunak (velum). Pangkal lidah menyentuh langit-langit lunak. Huruf [j] termasuk dalam bunyi laminopalatal, yaitu bunyi yang dihasilkan oleh keterlibatan tengah lidah (lamina) dan langit-langit keras (palatum). Tengah lidah menyentuh langitlangit keras (Muslich, 2010, p.52). Dengan demikian pengucapan huruf [j] pada kata [pagi] kurang tepat. Perubahan kata [pagi] menjadi [paji] karena pengaruh bahasa asing, khususnya bahasa Inggris. Dalam bahasa Inggris, huruf [g] dibaca [ji] sehingga mahasiswa menuturkan kata [pagi] menjadi [paji]. Untuk melafalkan huruf [g] dengan benar, mahasiswa harus memahami bagaimana pengucapan huruf tersebut. Huruf $[\mathrm{g}]$ dalam bahasa Indonesia juga biasa diujarkan oleh penutur asing, khususnya dalam mengujarkan kata [good], [god], [give], [game] dan lain-lain.

Mahasiswa harus melakukan tubian dalam melafalkan huruf $[\mathrm{g}]$ dengan benar. Soebardi (2005, p.12) memberikan contoh kosakata yang diawali dengan salah satu huruf dersol-velar tersebut. Kata tersebut adalah [gali], [gadis], [gila], [girang], [guru], [gunung], [goyang], [gelap], [gigi] dan beberapa kata yang lain. Dengan melakukan tubian terhadap contoh katakata tersebut diharapkan mahasiswa mampu melafalkan kata [pagi] dan beberapa kata yang mengandung huruf $[\mathrm{g}]$. Dosen harus membantu mahasiswa untuk mengetahui perbedaan titik artikulasi antara huruf [g] dan [j], sehingga mahasiswa mampu melafalkan huruf tersebut dengan benar.

Pada kesempatan lain, mahasiswa juga kurang tepat dalam mengujarkan kata [filəm]. Kata tersebut dilafalkan menjadi [filem]. Cara sederhana yang dapat dilakukan untuk memperbaiki kesalahan pengucapan kata tersebut yaitu dengan tubian. Untuk membedakan penggunaan antara huruf [e], [ə], dan [ع], Mayani, et al. (2008, p.xxii) memberikan contoh penggunaannya. Contoh penggunaan huruf [e] terdapat pada kata enak, merah, sore; penggunaan huruf [ə] terdapat pada əmpat, bəri, ritmə; dan contoh penggunaan huruf $[\varepsilon]$ terdapat pada kata kakek, nenck, bebek.

Djiwandono (2008, p.118) mengungkapkan berbicara berarti mengungkapkan pikiran secara lisan. Melalui ungkapan yang disampaikan kepada orang lain, seseorang dapat membuat orang lain memahami apa yang ada dalam pikirannya. Untuk dapat berbicara dalam suatu bahasa yang baik, pembicara harus menguasai lafal, struktur, dan kosakata yang bersangkutan (Nurgiyantoro, 2010, p.399).

\section{Kesalahan Sintaksis}

Mahasiswa bercerita di depan kelas tentang pengalamannya sewaktu berlibur ke Jakarta. Dosen mendengarkan cerita mahasiswa dengan antusias. Terkadang dosen memberikan umpan balik atas pernyataan yang disampaikan mahasiswa. Berikut bentuk ujaran yang dilakukan mahasiswa dan dosen.

(2)

Mahasiswa: Pada hari libur, [kita] pergi ke Jakarta. (22/TT/8/03/2012)

Dosen : Ha, kita, mengapa pilih kita? Kita dengan teman-teman?

Mahasiswa:Ya.

Dosen :Kami, kami. Bukan kita.

Mahasiswa:Kami?

Dosen :Ya, kami. E... Nooreehan, tahu bedanya kami dengan kita?

Mahasiswa: Apa?

Dosen : Kami itu, subjeknya yang diajak berbicara ikut serta, terlibat.

Tetapi kalau kita, misalnya, pada tanggal berapa kita pergi ke Bromo? (mahasiswa tidak menjawab). Kami pergi ke Bromo. Kami, boleh saya, boleh kamu, boleh anda bukan kita. Kalau kita ini semua. Jadi termasuk dia terlibat, karena dia tidak terlibat, jadi yang terlibat itu boleh memilih kata 'kami'. Kalau 'kita' berarti saya ikut ke Lampung, anda ikut ke lampung. Jadi kami, ya. Jadi, kami subjek, orang-orang yang diajak bicara ikut, kalau tidak ikut pilih 'kami' ya, kami. Anda dengan teman anda. Ok.

Mahasiswa kurang tepat dalam menggunakan kata ganti orang pertama jamak [kita] dalam kalimat [pada hari libur kita pergi ke Jakarta]. Seharusnya menggunakan kata ganti [kami]. Dosen memberikan penjelasan, jika subjek yang berbicara ikut dalam perjalanan ke Jakarta maka penggunaan [kita] tepat, tetapi karena tidak semua subjek yang diajak berbicara ikut, maka penggunaan kata ganti [kami] lebih tepat. Penggunaan kata ganti tersebut dinilai kurang tepat karena ketika mahasiswa bercerita di kelas tidak semua orang yang mendengarkan cerita tersebut ikut berlibur ke Jakarta.

Di lain pihak, terjadi fenomena menarik dalam penggunaan kata ganti [kami] bagi masyarakat Indonesia. Meskipun berdasarkan personanya telah dibedakan kata ganti atas diri pertama, kedua, dan ketiga, serta bentuk tunggal dan jamak, namun sering dijumpai pemakaian 
yang menyimpang dari pembagian tersebut. Kata [kami], sebenarnya adalah kata ganti orang pertama jamak, sering digunakan sebagai kata ganti orang pertama tunggal. Penggunaan kata ganti digunakan dengan tujuan untuk memberikan penghormatan kepada seseorang (Santoso, 1985, p.74).

Peran Bahasa Dosen Memberikan Koreksi Kesalahan Berbahasa

\section{Pengulangan}

Jenis koreksi kesalahan dalam bentuk pengulangan berfungsi untuk membetulkan bentuk kesalahan bahasa yang dilakukan pembelajar. Pengulangan memberikan pemahaman bagi pembelajar letak ketidaktepatan terhadap bagian kata atau kalimat. Pembelajar dapat mengetahui kata yang tepat jika dosen mengulangi suatu kata. Selain berfungsi untuk mengoreksi kesalahan, pengulangan juga dapat menegaskan bentuk kata yang dimaksud oleh dosen.

Penguasaan kosakata bahasa tertentu dapat mempengaruhi kompetensi seseorang terhadap bahasa yang ia gunakan. Seseorang yang menguasai kosakata bahasa Jawa tentu ia mampu berbahasa Jawa dengan baik. Sama halnya dengan peserta Darmasiswa. Agar dapat berkomunikasi dengan penutur, mereka harus menguasai kosakata bahasa target. Tarigan (1986, p.2) menyebutkan kualitas keterampilan berbahasa seseorang bergantung pada kuantitas dan kualitas kosakata yang dimilikinya. Ruddyanto (2009, p.5) juga menyebutkan bahwa belajar bahasa asing tentu tidak lepas dari upaya mempelajari kosakata. Tanpa penguasaan kosakata yang memadai pembelajar akan mendapatkan kesulitan untuk mempaktikkan materi yang dipelajarinya di kelas. Dari dua pendapat tersebut dapat ditarik kesimpulan bahwa semakin banyak seseorang atau pembelajar menguasai kosakata bahasa tertentu semakin baik pula kemampuan berbahasanya.

Bagi peserta Darmasiswa atau mahasiswa asing, kemampuan memahami kosakata bahasa Indonesia tidak hanya sebatas tahu artinya, mampu menuliskannya, tepat menyusunnya dalam sebuah kalimat, tetapi juga harus mampu mengujarkannya dengan tepat sehingga bentuk kata yang muncul sesuai dengan keinginan pembicara. Dengan kemampuan tersebut mahasiswa asing dapat meminimalisasi kesalahan yang terjadi. Bahkan mampu berbahasa Indonesia layaknya penutur.
Data $(01 / \mathrm{TT} / 3 / 11 / 2011)$ berikut ini diambil pada Kamis, 3 November 2011, pukul 10.15 WIB. Tempat pengambilan data tersebut berada di ruang kelas, pada proses pembelajaran berlangsung. Materi pembelajaran adalah menulis pengalaman karyawisata. Bahasa yang digunakan dalam pembelajaran bersifat campur kode antara bahasa Indonesia dan bahasa Inggris. Terdapat pula kesalahan yang dilakukan oleh mahasiswa. Berikut disajikan data ujaran yang disampaikan dosen dalam proses pembelajaran di kelas.

(3)

Dosen : Pankaj?

Mahasiswa 2:Yes.

Dosen : Ngantuk?

Mahasiswa: Ngantuk, [capex].

$(01 / \mathrm{TT} / 3 / 11 / 2011)$

Dosen : Ngantuk, capek. oke. Sekarang coba, di sana bagaimana hawanya, apa hawa, suasananya. hawa is Weather. Weather, sejuk. Malang is, Malang is sejuk. Apa sejuk. Fresh. (dosen menuliskan semua kata tersebut di papan tulis). Dingin, ya. Malang dingin. Kemudian apalagi?

Mahasiswa:Banyak hujan.

Data $(01 / \mathrm{TT} / 3 / 11 / 2011)$ tergolong kesalahan fonetik. Mahasiswa mengujarkan kata [capek] dengan bunyi ujaran [capex]. Bunyi ujaran mahasiswa yang paling menonjol terletak pada suku kata terakhir. Huruf [k] diujarkan menjadi $[\mathrm{x}]$. Dilihat dari cara gangguan arus udara oleh artikulator ketika bunyi diucapkan, huruf [k] termasuk bunyi stop, yaitu bunyi yang dihasilkan dengan cara arus udara ditutup rapat sehingga udara terhenti seketika, lalu dilepaskan kembali secara tiba-iba. Sebaliknya huruf $[\mathrm{x}]$ termasuk bunyi frikatif, yaitu bunyi yang dihasilkan dengan cara arus udara dihambat sedemikian rupa sehingga udara tetap dapat keluar (Muslich, 2010, p.55). Dilihat dari cara gangguan tersebut, jelas bahwa pengucapan bunyi [capex] kurang tepat, meskipun dilihat dari mekanisme artikulasi antara huruf [k] dan huruf $[\mathrm{x}]$ sama-sama tergolong bunyi dorsolvelar, yaitu bunyi yang dihasilkan oleh keterlibatan pangkal lidah (dorsum) dan langitlangit lunak (velum) (Muslich, 2010, p. 52).

Dilihat dari bentuk bibir ketika bunyi diucapkan, huruf [k] seperti bentuk vokal [a]. Vokal [a] yaitu huruf yang diucapkan dengan bentuk bibir dalam posisi netral, dalam arti tidak bulat tetapi juga tidak terbentang lebar. Huruf 
[x] diucapkan seperti bentuk vokal [e]. Vokal [e] yaitu huruf yang diucapkan dengan bentuk bibir tidak bulat atau terbentang lebar (Marsono, 2008, p.33-34)

Menurut hemat peneliti, bentuk bibir dalam mengujarkan huruf $[\mathrm{k}]$ hampir sama dengan bentuk bibir pada saat mengucapkan huruf [a], dan bentuk bibir dalam mengujarkan huruf $[\mathrm{x}]$ hampir sama dengan bentuk bibir ketika mengucapkan huruf [e]. Bentuk bibir pada pengucapan huruf [a] dan huruf [e] seolaholah tidak berbeda, tetapi dilihat dari ukurannya, huruf [a] lebih lebar bila dibandingkan dengan ukuran huruf [e].

Pengucapan kata [capek] dan [capex] seolah-olah tidak terdapat perbedaan yang mendasar karena kedua kata tersebut diujarkan dengan bentuk bibir yang hampir sama, yaitu bentuk bibir tak bulat. Dosen kemudian mengulangi bunyi ujaran [capek] sebagai respon atas bunyi ujaran yang dihasilkan mahasiswa. Koreksi yang dilakukan dosen adalah mengulangi bagian yang tidak tepat diujarkan pembelajar dengan perubahan fonetik dan melanjutkan dengan kalimat berikutnya.

Sudiani (2009, pp.14-15) menyebutkan berlibur sambil berlatih bahasa Indonesia yang dilakukan oleh mahasiswa Kajian Indonesia Fakultas Ilmu Sosial Universitas Flinders, Australia Selatan ke Nhill, Victoria selama tiga hari memberikan dampak positif bagi pembelajar bahasa Indonesia. Tempat duduk mahasiswa selama perjalanan sengaja diatur berselangseling dengan mahasiswa dari Indonesia. Kondisi duduk yang demikian membuat mahasiswa berkomunikasi dalam bahasa Indonesia dengan teman sebangku. Pemandangan yang indah selama perjalanan, pengalaman berlibur dan pengalaman belajar bahasa Indonesia menjadi bahan komunikasi di kereta. Mahasiswa belajar sejumlah kata-kata baru berkaitan dengan alam seperti [mangsa], [pemangsa], [vegetasi], [gurun], [kodok], dan sebagainya.

\section{Mengubah}

Mengubah adalah koreksi umpan balik yang dilakukan oleh dosen dalam merumuskan ulang atau memperluas sebuah ujaran kurang tepat dengan cara halus. Dalam mengubah ujaran yang kurang tepat, dosen tidak serta-merta memberikan bentuk ujaran yang tepat. Dosen akan memberikan bentuk ujaran yang tepat dalam kalimat yang berbeda. Dengan cara tersebut, pembelajar dapat menerima koreksi tanpa merasa mendapatkan koreksi secara langsung.
Tugas perkuliahan berikutnya, mahasiswa harus menulis pengalaman berkaryawisata. Dosen memberikan kata-kata kunci atau kosakata yang berhubungan dengan keindahan alam. Dosen menulis beberapa kosakata seperti: hawa, sejuk, taman, indah, hujan, pohon, bersih, kabut, dan beberapa kata lain. Kata-kata yang ditulis dosen di papan tulis merupakan usulan dari mahasiswa. Dalam interaksi pembelajaran, mahasiswa sering menggunakan frasa menerangkan-diterangkan (M-D) dan campur kode. Dalam bahasa Indonesia, pola struktur yang terbentuk dalam frasa biasanya berpola diterangkan-menerangkan (D-M). Tetapi banyak pula yang menggunakan struktur menerangkan-diterangkan (M-D). Suhardi (2008, p.66) memberikan contoh struktur frasa yang berkontruksi DM dan M-D seperti berikut ini.

(a). Masyarakat madani

D $\quad M$

(b). Sangat menyenangkan

M D

Contoh frasa (a) dan (b) tersebut tergolong jenis frasa endosentrik atributif. Frasa tersebut terdiri atas unsur pusat atau unsur yang menerangkan dan unsur atribut atau unsur yang menerangkan. Kata [madani] menerangkan kata [masyarakat], kata [sangat] menerangkan kata [menyenangkan].

Struktur kalimat yang dibentuk mahasiswa terdapat beberapa kesalahan. Secara makna kalimat yang dihasilkan mahasiswa dapat dipahami tetapi secara struktur kurang tepat. Dosen memberikan perbaikan terhadap kesalahan tersebut agar tidak terjadi kesalahan-kesalahan berikutnya. Berikut bentuk ujaran yang disampaikan oleh mahasiswa.

(3)

Mahasiswa: Banyak [bagus park]. $(02 / \mathrm{TT} / 3 / 11 / 2011)$

Dosen : Park, taman yang bagus. Taman, garden, park, lapangan ya.

Mahasiswa: Ya.

Data (02/TT/3/11/2011) dapat diketahui bahwa mahasiswa menggunakan campur kode dalam mengungkapkan konsep taman yang indah atau taman yang bagus. Kesalahan yang terjadi adalah penggunaan frasa [bagus park]. Ketidaktepatan ini karena interferensi bahasa asing. Selain ketidaktepatan penggunaan kode bahasa asing, mahasiswa juga menggunakan struktur yang kurang tepat, yang berpola mene- 


\section{LingTera, 2 (1), Mei 2015 - 45 \\ Ngatma'in, Suhardi}

rangkan-diterangkan (M-D). Seharusnya frasa tersebut berpola diterangkan-menerangkan (DM).

Penggunaan campur kode dalam peristiwa komunikasi secara alami dapat terjadi karena pengguasaan kosakata bahasa target (bahasa Indonesia) masih sedikit. Untuk membenarkan kesalahan frasa, dosen mengubah struktur frasa menjadi yang lebih tepat. Dalam melakukan koreksi kesalahan dosen tidak serta merta menyalahkan bentuk ujaran yang dihasilkan mahasiswa tetapi justru memberikan koreksi implisit atau umpan balik korektif yang merumuskan ulang atau memperluas sebuah ujaran tidak tepat dengan cara yang lebih halus. Cara koreksi yang dilakukan dosen ialah memberikan padanan kata [park] dengan kata yang lain yaitu [taman], [garden], dan [lapangan]. Dengan cara tersebut mahasiswa akan memiliki kepercayaan diri yang besar untuk menggunakan bahasa target dalam peristiwa komunikasi. Sartinah Hardjono (1988, p.71) mengungkapkan bahwa dilihat dari segi psikologi, kosakata asing berfungsi sebagai (1) stimulus yang kompleks dalam persepsi dan penangkapan bahasa lisan maupun tulis, (2) suatu reaksi seorang yang kompleks dalam mengungkapkan diri secara lisan maupun tulis. Kata penangkapan dapat pula bermakna pemahaman atau keterampilan reseptif, sedangkan kata mengungkapkan diri dapat pula bermakna pengungkapan pikiran atau keterampilan produktif. Yang tergolong dalam keterampilan reseptif adalah menyimak dan membaca. Keterampilan berbicara dan menulis tergolong keterampilan produktif. Dari dua konsep tersebut dapat diberikan benang merah bahwa penguasaan kosakata membantu pembelajar menguasai bahasa target, baik lisan maupun tulis.

Sriasih (2009, pp.12-14) menguraikan beberapa manfaat kegiatan berpasangan dan berkelompok dalam pengajaran BIPA. Pertama, meningkatkan kepercayaan diri pembelajar untuk berkomunikasi. Kedua, menciptakan tempat yang aman bagi pembelajar untuk berlatih dan menerima masukan dari teman. Ketiga, meningkatkan kemampuan pembelajar untuk mengoreksi kesalahan sendiri tanpa harus dosen yang melakukannya.

\section{Peran Bahasa Penutur (foreigner-talk) dalam Memberikan Koreksi Kesalahan Berbahasa Indonesia Peserta Darmasiswa}

Richards, Platt, \& Platt (1992, p.142) menjelaskan bahwa bahasa penutur (foreignertalk) adalah tipe bahasa yang digunakan penutur ketika berbicara dengan penutur asing yang kurang mampu berbahasa asing. Bahasa penutur memiliki peranan yang cukup tinggi dalam proses pembelajaran bahasa Indonesia bagi peserta Darmasiswa. Bahasa penutur berfungsi sebagai model pembelajaran secara langsung bagi peserta Darmasiswa. Mahasiswa akan belajar penggunaan bahasa Indonesia secara kontekstual yang terjadi di masyarakat.

Bahasa penutur menurut Ferguson (Brulhart, 1986, p.29) adalah sebuah register komunikasi yang disederhanakan. Digunakan oleh penutur untuk orang asing yang memiliki perintah atau kosakata bahasa target yang sangat terbatas atau tidak memiliki pengetahuan sama sekali. Peran bahasa penutur memberikan koreksi kesalahan berbahasa peserta Darmasiswa dalam hal kesalahan fonologis, kesalahan sintaksis, dan kesalahan leksikon. Jenis koreksi yang dilakukan berupa pengulangan, mengubah, dan koreksi eksplisit. Kajian ini hanya memaparkan beberapa jenis kesalahan berbahasa peserta Darmasiswa dan peran bahasa penutur memberikan koreksi kesalahan. Jenis kesalahan dan jenis koreksi kesalahan dideskripsikan sebagai berikut.

Jenis Kesalahan Berbahasa Peserta Darmasiswa

\section{Kesalahan Fonologis}

Peserta Darmasiswa yang sering menggunakan bahasa Indonesia akan semakin baik dalam menyimak dan mengujarkan suatu kata atau kalimat. Semakin sering bahasa Indonesia digunakan, peserta Darmasiswa memiliki keterampilan berbahasa yang baik pula.

Mahasiswa menuturkan bahwa ia sedang berpuasa. Ia tidak boleh makan nasi, lauk, atau pun sayur. Yang boleh dimakan hanya buah. Berikut ini bentuk tuturan yang dilakukan penutur dan mahasiswa.

(4)

Penutur : Puasa nasi. Puasa nasi.

Mahasiswa:Ya, puasa nasi, ikan, ayam, tidak boleh. [Hana] buah.

Penutur :Hanya buah. (11/FT/12/01/2012)

Mahasiswa kurang mampu mengujarkan bunyi nasal (ñ). Untuk mengujarkan kata [haña] mahasiswa mengalami kesalahan, sehingga kata yang keluar berbunyi [hana]. Bahasa Inggris

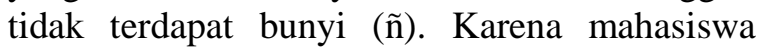
memiliki latar belakang kompetensi berbahasa Inggris, mahasiswa perlu mengujarkan kata [haña] berulang-ulang. Penutur membenarkan 


\section{LingTera, 2 (1), Mei 2015 - 46 \\ Ngatma'in, Suhardi}

kata yang salah tersebut dengan cara mengulangi dalam ujaran.

\section{Kesalahan Leksikon}

Peristiwa komunikasi yang berlangsung antara penutur dengan pembelajar bahasa kedua pasti akan mengalami interferensi bahasa pertama. Peristiwa itu dapat berpengaruh negatif, tetapi interferensi juga dapat memberikan pengaruh positif. Pengaruh negatif muncul apabila penutur bersih kukuh menggunakan bahasa asing dalam berkomunikasi. Pengaruh positifnya, bahasa asing yang dipakai dapat memberikan khazanah kosakata bagi lawan tutur komunikasi.

Topik komunikasi antara penutur dan mahasiswa seputar minuman dan buah. Berikut bentuk ujaran penutur dan mahasiswa. Mahasiswa menceritakan jenis buah yang terdapat di negara Nepal. Selain pisang, nanas, apel, dan semangka, di Negara Nepal juga terdapat buah rambutan. Untuk menceritakan buah rambutan mahasiswa menggunakan gestur dan memegang rambutya. Berikut komunikasi yang sedang berlangsung antara penutur dan mahasiswa.

(5)

Penutur : Di Nepal banyak buah, buah?

Mahasiswa: Ya, buah, buah. You know pasang, mangga, apel, manas. Manas?

Penutur : Nanas.

Mahasiswa: Ya, nanas. Water melon is apa itu?

Penutur : Semangka.

Mahasiswa: [Semangga], [semangga] and leci and you know [rambut], [rambut?] (16/FT/12/01/2012)

Penutur : Rambutan.

Mahasiswa: Rambutan, ya rambutan.

Penutur : Ini rambut (sambil memegang rambut).

Mahasiswa:Ya, rambut, rambutan.

Data (6) ditunjukkan bahwa mahasiswa kurang tepat dalam menuturkan kata [pisang]. Kata tersebut dituturkan dengan kata [pasang]. Kesalahan tersebut tidak dikoreksi oleh penutur karena ujaran mahasiswa terlalu cepat. Untuk menuturkan kata [rambutan], mahasiswa menuturkannya [rambut]. Penutur memberikan koreksi secara langsung terhadap kesalahan kata tersebut. Mahasiswa mampu mengujarkan kata [manga] tetapi tidak mampu mengujarkan kata [semanka]. Kata [semanka] diujarkan menjadi [semanga]. kata yang memiliki bunyi [y] terasa sulit diujarkan mahasiswa. Samsuri (1980, p.9) menguraikan bahwa dalam bahasa Inggris belum pernah ditemukan kata yang memiliki bunyi [ $\mathrm{y}]$ pada awal kalimat.

Dardjowidjojo (1997, p.33) menuturkan kenapa orang Indonesia dapat mengucapkan kata 'ngomong, ngopi, ngomel' dengan bunyi [y] pada awal suku karena masukan itu sejak kecil pada bagian Wernicke, jalur Orlandic, dan daerah Broca sudah terlatih untuk mengucapkan bunyi [y] pada awal suku. Sebaliknya, orang Amerika tidak terlatih demikian sehingga dalam konsep mentalnya kata [singa] dirasakan sebagai [si] dan [a]; karena itu muncul bunyi [g] sebelum [a]. Mengenai kata singging, dalam bahasa Inggris ada aturannya, yakni pada kata yang berakhir dengan [y] dan kata ini kemudian mendapat infleksi [i门] ucapannya menjadi [sinin], dan bukan [singin].

Dari peristiwa ujaran yang dilakukan mahasiswa dapat diberikan catatan bahwa setiap kosakata yang memiliki huruf [y] akan diberi tambahan huruf [g]. Contohnya yaitu, mahasiswa mampu mengujarkan kata [manga] dengan tepat tetapi kurang mampu mengujarkan kata [səmanka].

\section{Peran Bahasa Penutur Memberikan Koreksi}

Kesalahan Berbahasa

\section{Pengulangan}

Tempat komunikasi antara penutur dan mahasiswa sangat bervariasi. Terkadang terjadi di kantin kampus, pasar, atau tempat wisata. Berikut ini situasi komunikasi yang berlangsung antara penutur dan mahasiswa dengan setting kantin Universitas. Mahasiswa dan penutur saling menceritakan pengalaman dan kebudayaan negara.

(6)

Penutur :Pankaj, mengapa kamu tidak makan. Mahasiswa: [Kuasa]. Hehehe.

(10/FT/12/01/2012)

Penutur : Puasa nasi. Puasa nasi.

Mahasiswa: Ya, puasa nasi, ikan, ayam. Tidak boleh. Hana buah.

Data (10/FT/12/01/2012) ditunjukan bahwa mahasiswa salah dalam menuturkan kata [puasa]. Kata [puasa] diucapkan menjadi [kuasa]. Hal ini terjadi karena antara bibir atas dan bibir bawah tidak bertemu sehingga kata yang muncul tidak [puasa] tetapi [kuasa]. Kesalahan fonologis tersebut berdampak pada perbedaan makna kata yang diujarkan mahasiswa. Kata [puasa] bermakna menghindari makan dan minum dengan sengaja (Depdiknas, 2008, 
p.1110). Kata [kuasa] bermakna kemampuan atau kesanggupan untuk berbuat sesuatu (Depdiknas, 2008, p.746). Pengujaran kata [kuasa] oleh mahasiswa kurang tepat. Muslich (2010, pp.51-52) menguraikan bahwa huruf [p] merupakan bunyi bilabial, yaitu bunyi yang dihasilkan oleh keterlibatan bibir (labium) bawah dan bibir (labium) atas. Huruf [k] merupakan bunyi dorso-velar, yaitu bunyi yang dihasilkan oleh keterlibatan pangkal lidah (dorsum) dengan langit-langit lunak (uvula). Penutur membenarkan kata tersebut dengan cara mengulangnya kata [puasa] sebanyak dua kali.

\section{Mengubah}

Tindak komunikasi yang berlangsung antara penutur dan mahasiswa cenderung menggunakan struktur yang sederhana. Kosakata yang digunakan sangat umum. Penutur cenderung menggunakan kalimat dengan frekuensi kecepatan yang standar. Tidak terlalu cepat atau pun lambat. Secara makna semua ujaran dapat dimengerti mahasiswa. Secara fonologis ujaran yang disampaikan penutur dapat pahami secara penuh oleh mahasiswa. Dalam menuturkan kata tertentu, mahasiswa masih mengalami kesalahan. Berikut disajikan bentuk komunikasi yang berlangsung antara mahasiswa dan penutur.

(7)

Mahasiswa: Winter, winter, dinggin.

Mahasiswa 2: Basah, [basah musim]. (20/FT/12/01/2012)

Penutur :Oh ya. Musim hujan.

Data (20/FT/12/01/2012) ditunjukkan komunikasi yang berlangsung antara mahasiswa dan penutur tentang pergantian musim di Indonesia. Ada musim hujan, ada pula musim kemarau. Ketika salah satu mahasiswa menuturkan winter, mahasiswa lain menanggapinya dengan frasa [basah musim].

Kesalahan yang terjadi dalam peristiwa komunikasi terletak pada pemilihan diksi. Mahasiswa kurang tepat dalam menguraikan musim hujan. Ia mengatakannya dengan istilah [basah musim]. Mahasiswa sudah memahami konsep musin hujan, hanya kurang tepat dalam pemilihan kosakata atau leksikon. Sehingga ia menggunakan kata [basah]. Di Indonesia tidak menggunakan istilah [musim basah]. Istilah yang digunakan adalah [musim hujan]. Penutur memberikan koreksi atas kesalahan yang dilakukan mahasiswa dengan cara mengubahnya menjadi [musim hujan].

\section{Peran Bahasa-Antara (interlanguage-talk) dalam Koreksi Kesalahan Berbahasa Indonesia.}

Richards \& Renandya (Eds.) (2003, p.13) mengemukakan pembelajar bahasa kedua cenderung melalui proses sistematis atau sistematis semu dalam perkembangan bahasanya sampai mereka mampu memiliki kompetensi bahasa target secara penuh. Keberhasilan bahasa-antara karena beberapa faktor yang mempengaruhinya. Faktor tersebut adalah umpan balik dari pembelajar lainnya dan dosen. Selinker (Azzouz, 2008, p.24) memberi pengertian bahasa-antara adalah bahasa menengah dari setiap pembelajar atau pemeroleh suatu bahasa. Pembelajar harus menemukan cara untuk mempelajari bahasa target.

Bahasa-antara dapat muncul apabila ada kesempatan bagi mahasiswa untuk menggunakan bahasa target secara leluasa. Situasi-situasi tersebut dapat tercipta dalam suasana tawarmenawar barang atau kegiatan lainnya. Situasi nonformal, situasi santai dapat memicu munculnya bahasa-antara. Meskipun bahasa yang dihasilkan peserta Darmasiswa bersifat campur kode.

Long \& Porter (Crossley \& McNamara, 2010, p.230) menyebutkan bahwa bahasa-antara di kelas bahasa kedua memberikan pembelajaran penting karena antara pembelajar saling memberikan peluang untuk praktik dan meningkatkan kemampuan dalam menguasai bahasa target. Bahasa-antara memberikan koreksi kesalahan berbahasa peserta Darmasiswa dalam hal kesalahan fonologis dan kesalahan leksikon. Jenis koreksi yang dilakukan berupa koreksi diri dan koreksi teman.

Kajian ini hanya memaparkan beberapa jenis kesalahan berbahasa peserta Darmasiswa dan peran bahasa-antara memberikan koreksi kesalahan. Jenis kesalahan dan jenis koreksi kesalahan dideskripsikan sebagai berikut.

Jenis Kesalahan Berbahasa Peserta Darmasiswa

\section{Kesalahan Fonologi}

Sesuatu yang wajar apabila pembelajar bahasa asing mengalami kesalahan dalam berbicara atau menyimak bahasa target. Pada peristiwa komunikasi yang berlangsung, mahasiswa mampu mengoreksi kesalahan yang dilakukan, terkadang pula ia tidak mampu melakukannya. Berikut tindak komunikasi yang dilakukan antarmahasiswa. Mahasiswa belajar secara kontekstual, yaitu belajar langsung di pasar tradisional. Dosen mendampingi mahasiswa ketika 


\section{LingTera, 2 (1), Mei 2015 - 48 \\ Ngatma'in, Suhardi}

berbelanja di pasar. Mahasiswa berdiskusi jenis kebutuhan apa yang dibeli.

(8)

Mahasiswa: [Setenah], setengah kilo.

(72/IT/21/03/2012)

Mahasiswa 2: Saya membeli ini, lima ribu. Setengah kilo in lima ribu.

Mahasiswa: Berapa?

Mahasiswa 2: Lima, lima.

Mahasiswa: Lima.

Mahasiswa 2:Ya, lima jeruk

Mahasiswa mampu membetulkan kesalahan kata secara fonetik. Mahasiswa menyadari bahwa kata [sətənah] salah. Ia segera membenarkan kata tersebut menjadi [sətəyah]. Dalam situasi kontekstual, mahasiswa mau dan mampu menggunakan bahasa Indonesia dengan baik, meskipun masih terdapat campur kode misalnya kata $[i n]$ dalam kalimat [Saya membeli ini, lima ribu. Setengah kilo in lima ribu].

Mahasiswa cenderung menggunakan bahasa Indonesia. Kedua mahasiswa saling memahami maksud antarkomunikan. Meskipun penutur kedua menggunakan campur kode dalam kalimatnya [Saya membeli ini, lima ribu. Setengah kilo in lima ribu]. Penutur pertama tetap memahami seluruh makna kalimat dan balik bertanya [berapa?]. Secara fonologis, struktur, dan makna dapat dipahami oleh keduanya. Di sinilah fungsi bahasa-antara selain sebagai tempat berlatih menguasai bahasa target. Bahasa antara juga berfungsi sebagai model, koreksi, dan pembanding peserta Darmasiswa dalam berinteraksi dengan sesama peserta Darmasiswa, penutur asli, dan dosen.

\section{Kesalahan Leksikon}

Dalam pemilihan diksi, mahasiswa juga masih mengalami kesalahan. Dalam situasi komunikasi yang lain, mahasiswa justru mampu memberikan koreksi terhadap kesalahan yang dilakukan. Berikut bentuk koreksi yang dilakukan mahasiswa dalam kesalahan berbahasa.

(9)

Mahasiswa: Kalau mau beli [baya], jubah? $(03 / \mathrm{IT} / 9 / 01 / 2012)$

Penutur : Jubah?

Mahasiswa: Di mana?

Penggunaan kata [baya] dalam data (03/IT/9/01/2012) kurang tepat. Kata [baya] dalam bahasa Indonesia memiliki makna umur (Depdiknas, 2008, p.151). Mahasiswa memahami kata [baya] tersebut salah namun maha- siswa tidak mampu untuk mengatakan kata yang lebih tepat yaitu kata [kebaya]. Mahasiswa memberikan padanan kata lain yaitu kata [jubah]. Depdiknas (2008, p.590) menguraikan kata [jubah] memiliki makna baju panjang (sampai di bawah lutut), berlengan panjang. Bentuk koreksi kesalahan kata benda [baya] yang dilakukan mahasiswa tergolong koreksi diri. Koreksi diri adalah koreksi yang dilakukan oleh mahasiswa sendiri.

Peran Bahasa-Antara Memberikan Koreksi Kesalahan Berbahasa

\section{Koreksi Diri}

Koreksi diri adalah koreksi yang dilakukan oleh diri sendiri. Koreksi yang dilakukan pembelajar karena menyadari bahwa ia telah melakukan kesalahan terhadap ujaran yang dihasilkan. Biasanya koreksi jenis ini dilakukan oleh pembelajar dalam waktu yang relatif singkat setelah ia memahami bahwa ada ujaran yang kurang tepat. Bahasa-antara memberikan keuntungan bagi peserta Darmasiswa. Keuntungan yang didapat adalah koreksi diri dalam peristiwa komunikasi. Koreksi yang muncul tidak sama dengan koreksi yang dilakukan oleh dosen, misalnya koreksi kesalahan kata ganti atau kesalahan imbuhan tetapi masih sebatas kesalahan fonologi dan kesalahan leksikon.

Mahasiswa bercerita di depan kelas. Ia menceritakan tanggal kelahiran, hobi, dan kebiasaan makan. Ketika ia mengujarkan kata film, mahasiswa melakukan kesalahan. Mahasiswa bersegera memperbaiki kesalahan kata tersebut. Berikut bentuk tuturan yang dilakukan mahasiswa.

(10)

Mahasiswa: Saya lahir pada tanggal sepuluh Januari seribu sembilan ratus delapan puluh delapan. Saya lahir di rumah sakit. Hobi saya itu membaca buku. Buku yang saya sangat suka komik Jepang. Dan saya sangat suka menonton [filem], filəm. Setiap hari saya biasa sarapan pukul sepuluh pagi. Makan siang pada sore. Makan, makan malam. (59/IT/15/03/2012)

Mahasiswa mampu memperbaiki kesalahan fonetik. Ketika ia mengujarkan kata [filem] secepatnya ia melafalkan bentuk yang benar yaitu [filəm]. Perbaikan terhadap kesalahan kata tersebut dapat dilakukan mahasiswa karena dalam kesempatan yang berbeda dosen sudah memberikan koreksi terhadap kesalahan kata 


\section{LingTera, 2 (1), Mei 2015 - 49 \\ Ngatma'in, Suhardi}

tersebut. Dengan koreksi yang diberikan sebelumnya, mahasiswa mengetahui bentuk kesalahan kata yang diujarkan. Dengan demikian, sewaktu ia mengetahui bahwa kata yang diujarkan salah, ia bersegera memperbaikinya.

\section{Koreksi Teman}

Mahasiswa mampu memberikan koreksi terhadap kesalahan leksikon yang dilakukan temannya. Mahasiswa yang melakukan kesalahan akhirnya mengikuti petunjuk yang diberikan temannya. Berikut bentuk tuturan yang dilakukan oleh mahasiswa.

(11)

Mahasiswa: Dan belajar di esempe (SMP) negeri di Madagaskar. Tanggal lahirnya e... hari lima, lima puluh.

Dosen :Heh? (dosen dan mahasiswa tertawa) dua puluh lima.

Mahasiswa: Ya, dua puluh lima. Dua puluh lima bulan Oktober tahun [sebelas sepuluh sembilan ratus].... (51/IT/15/03/2012)

Mahasiswa 2: Seribu, seribu.

Mahasiswa: Seribu sembilan ratus sembilan lima.

Dosen : Sembilan puluh lima.

Kesalahan pada data (51/IT/15/03/2012) tergolong kesalahan leksikon, yaitu kata bilangan. Mahasiswa sudah mampu membetulkan kesalahan frasa [sebelas sepuluh sembilan ratus] yang dilakukan penutur. Penutur mengulangi kosakata yang lebih tepat setelah mendapat perbaikan dari pembelajar lain.

\section{SIMPULAN DAN SARAN}

\section{Simpulan}

Penelitian ini menemukan beberapa peran bahasa dosen, bahasa penutur, bahasa-antara dan jenis koreksi kesalahan yang dilakukan oleh dosen, penutur dan mahasiswa dalam pembelajaran berbahasa Indonesia bagi peserta Darmasiswa. Pertama, peran bahasa dosen (teachertalk) memberikan koreksi kesalahan berbahasa Indonesia peserta Darmasiswa dalam hal kesalahan fonologis, kesalahan sintaksis, kesalahan leksikon, dan kesalahan morfologis. Jenis koreksi yang dilakukan berupa: pengulangan, mengubah, koreksi eksplisit, pancingan, dan klarifikasi.

Kedua, peran bahasa penutur (foreignertalk) memberikan koreksi kesalahan berbahasa Indonesia peserta Darmasiswa dalam hal kesalahan fonologis, kesalahan sintaksis, dan kesalahan leksikon. Jenis koreksi yang dilakukan berupa: pengulangan, mengubah, dan koreksi eksplisit.

Ketiga, peran bahasa-antara (interlanguage-talk) memberikan koreksi kesalahan berbahasa Indonesia meliputi: kesalahan fonologis dan kesalahan leksikon. Jenis koreksi yang dilakukan berupa: koreksi dari diri sendiri dan koreksi dari teman.

\section{Saran}

Saran penelitian ini adalah (1) untuk mengetahui bentuk kesalahan fonetik secara akurat, hendaknya dilakukan penelitian yang berbasis komputerisasi, dan (2) agar dapat memberikan gambaran tentang bentuk-bentuk kesalahan yang dilakukan peserta Darmasiswa, perlu dilakukan pemilihan atau penambahan jumlah sampel yang terdiri atas beberapa negara atau benua.

\section{DAFTAR PUSTAKA}

Azzouz, A. (2008). The effect of age upon sla. Tesis magister, tidak diterbitkan, University of Aleppo, Syria.

Brown, H.D. (2008). Prinsip pembelajaran dan pengajaran bahasa. $\left(5^{\text {th }} \mathrm{ed}\right.$.). (Terjemahan Noor Cholis \& Yusi Avianto Pareanom). New York: Pearson Education. (Buku asli diterbitkan tahun 2007).

Brulhart, M. (November 1986). Foreigner talk in the esl classroom: interactional adjustments to adult students at two language proficiency levels [versi elektronik]. Tesl Canada Journal/Revue Tesl Du Canada Special Issue 1, pp.29-42.

Crossley, S.A. \& McNamara, D.S. (Mei 2010). Interlanguage talk: what can breadth of knowledge features tell us about input and output differences? [Versi Elektronik]. Proceedings of the Twenty-Third International Florida Artificial Intelligence Research Society Conference (flairs 2010), pp.229-234.

Dardjowidjojo, S. (1997). Echa perkembangan bahasa anak Indonesia dua belas-dua puluh empat bulan. Pelba, 10, pp.1-37.

Depdiknas. (2008). Kamus besar bahasa Indonesia. $\left(4^{\text {th }}\right.$ ed.). Jakarta: Pusat Bahasa.

Djiwandono, M. Soenardi. (2008). Tes bahasa pegangan bagi pengajar bahasa. Jakarta: PT Indeks. 


\section{LingTera, 2 (1), Mei 2015 - 50 \\ Ngatma'in, Suhardi}

Hardjono, S. (1988). Psikologi belajar mengajar bahasa asing. Jakarta: Departeman Pendidikan dan Kebudayaan.

Harimansyah W, G, et al. (2008). Pengembangan model pembelajaran: Uji efektivitas bahan ajar bipa. Jakarta: Pusat Bahasa.

Iskandarwassid \& Sunendar, H. D. (2009). Strategi pembelajaran bahasa. $\left(2^{\text {th }} \mathrm{ed}\right.$.). Bandung: Pascasarjana UI dan Remaja Rosdakarya.

Krashen, S.D. (2002). Second language acquisition and second language learning. Oxford: Pergamon Press.

Santoso, Kusno Budi. (1985). Pengantar tata bahasa Indonesia. Bandung: Rosda.

Mayani, L A, et al. (2008). Tingkat Pemula Lentera Indonesia 1 penerang untuk memahami masyarakat dan budaya indonesia.Jakarta: Pusat Bahasa.

Moleong, L.J. (2012). Metode penelitian kualitatif. $\left(30^{\text {th }} e d.\right) . \quad$ Bandung: Remaja Rosdakarya.

Mahsun. (2012). Metode penelitian bahasa tahapan strategi, metode, dan tekniknya. ( $6^{\text {th }}$ ed.). Jakarta: Rajawali Pers.

Marsono. (2008). Fonetik.( $6^{\text {th }}$ ed.) Yogyakarta: Gajah Mada University Press.

Muslich, M. (2010). Fonologi bahasa Indonesia tinjauan deskriptif sistem bunyi bahasa Indonesia. $\left(3^{\text {th }}\right.$ ed.) Jakarta: Bumi Aksara.

MA Xiao-yan. (2006). Teacher talk and efl in university classrooms. Tesis magister, tidak diterbitkan, Chongqing Normal University \& Yangtze Normal University, China.

Nurgiyantoro, B. (2010). Penilaian pembelajaran bahasa berbasis kompetensi. ( $I^{\text {th }}$ ed.). Yogyakarta: BPFE.
Richards, J.C., Platt, J., \& Platt, H. (1992). Longman dictionary of language teaching and applied linguistics. Harlow: Longman.

Richards, J.C. \& Renandya, W.A. (Eds.). (2003). Methodology in language teaching ( $\left.2^{\text {th }} e d.\right)$. New York: Cambridge University Press.

Ruddyanto, C. (November 2009). Perkembangan kosakata: salah satu masalah di dalam pemelajaran bahasa asing [Versi elektronik]. Buletin Pengajaran bipa. Edisi 2/3, pp.5-6.

Samsuri. (1980). Analisa bahasa memahami bahasa secara ilmiah. $\left(2^{\text {th }}\right.$ ed.). Jakarta: Erlangga.

Setiyadi, B. (2006). Metode penelitian untuk pengajaran bahasa asing pendekatan kuantitatif dan kualitatif. Yogyakarta: Graha Ilmu.

Soebardi, S. (1995). Learn bahasa Indonesia 1. Jakarta: Bhratara.

Sriasih, L. (Juli 2009). Aktivitas berpasangan dan berkelompok yang efektif, menyenangkan dan bermakna dalam pengajaran bipa [Versi elektronik]. Buletin Pengajaran bipa, Edisi 2/2-Juli, 12-14.

Sudiani, A. (November 2009). Berlibur sambil berlatih bahasa Indonesia. [Versi elektronik]. Buletin Pengajaran bipa. 2/3. pp.14-15.

Sugiyono. (2010) Metode penelitian pendidikan pendekatan kuantitatif, kualitatif, dan $r$ $\& d .\left(5^{\text {th }} e d.\right)$. Bandung: Alfa Beta.

Suhardi. (2008). Sintaksis. Yogyakarta: UNY Press.

Tarigan, H.G. (1986). Pengajaran kosakata. Bandung: Angkasa. 